\title{
Effects of Commercial Activities on Transportation Route in Urban Centres in Nigeria: A Case Study of Oba Adesida Road, Akure
}

\author{
OWOLABI, Babatunde Oluwaseyi (Ph.D)
}

Department of Urban and Regional Planning, Federal University of Technology, Akure

\begin{abstract}
Every geographical region (continent, nation, state and local government) constitutes a system characterized by transport network. The research aims at examining Effects of Commercial Activities on Transportation Route in Urban Centres in Nigeria: A case study of Oba Adesida Road, Akure. It identifies the socio-economic impact of commercial activities on urban transportation system and the usefulness of traffic control to minimize traffic congestion in the study area. The data was collected through observation, questionnaire administration and personal interview survey and secondary source such as photograph and maps adopting simple random sampling with 250 questionnaires. Three (3) sets of questionnaires were used to elicit relevant data for the study. The first set of questionnaires of 100 (9\% of the 1,150 stalls) focused on the seller who are stall owners for the assessment of economic impact of commercial activities in the study areas. The second set of 100 questionnaires (0.16\% of the 63,340 households of Akure), focused on the buyers who patronize the market place for their daily need to respond to the level of patronage in study areas. The last set of 50 questionnaires (16\% of 300 cars that make use of the car park) were directed to drivers who ply the road often to their respective place of work, the car park was the target area for the drivers. However, analysis of the data embraced the usage of statistical package for social science (SPSS). The research revealed that the significant of urban transportation system is not just a factor affected by commercial activities but as a factor that link and relate other factors such as urban growth. It showed that mode of transit and increase in market visitation has resulted into increase in traffic congestion. Conclusively, commercial activities affect the transportation system and invariably has environmental side effects. The problem of traffic and environmental issues should be checked through the eradication of on-street trading, fining the drivers that involved in onstreet parking, they should be mandated to use the parking lot around the area.
\end{abstract}

Keywords: Transportation, Route, Commercial activities, Urban centres, Nigeria

\section{INTRODUCTION}

Urban transport problems remain one of the most nagging problems in urban transportations today. All over the world, steps have been taken to tackle the problems, but all to no avail, only seem to get worse, these problems surface when cities expand without control due to increase in population from rural to urban centres (Aderamo, 2012). Various approaches have been taken to combat urban transport problems. In ancient Rome for example, Julius Caesar once prohibited the movement of cars during day light to relieve traffic congestion on roads (Yago, 1983). Commercial areas in a city structure can take up to about $5 \%$ of the city's land and it is used mainly for commercial activities, which are characterized by effort of people providing goods and services and the patronage of costumers to the business vendors. These activities ensure the functionality of the city and most often determines the growth of a city, examples of the activities are; food items, boutique, electronics and computer accessories, kitchen utensils, banks, bookshops, filling stations, financial establishments, and wide variety of services that are broadly classified as "business". They provide jobs and bring money into the community. Generally, a significant proportion of those who find employment in the urban informal sector in the developing areas engage in the buying and selling of goods as the population of cities in those areas continues to grow (Churchill et al, 1976).

According to Okoko (2006), transportation can be defined as a process that involves the movement of commuters, goods and services from a given point of origin to a specific destination. However, transportation plays major role in urban development and on city growth, being a major urban land use element (Okoko, 2006). It promotes the development of various activities that foster its economic 
development, provides necessary channels of communication and interaction. Transportation route is part of distinct development pattern or road network and mostly described by regular street patterns as an indispensable factor of human existence, development and civilization.

\subsection{Statement of Research Problem}

The level of urbanization in the developing world indicates that more people now live in cities than before. Cities with one million people and above, according to the United Nations forecasts increased to over 300 by the year 2000 in the developing world (Ogunbodede 2009). This trend will continue because of the rapid growth in population, resulting from improvement in health services and the multifarious functions performed by cities, which have been another major attractive force. The situation as described above has its impact on traffic congestion in the cities of developing world. Thus, the activities, which take place in them, make them generators and attractors of traffic, which, of course, has implications on mobility (Ogunbodede, 2009). Traffic congestion is a problem that emanates when a city's road network is unable to accommodate the volume of traffic, which is caused by rapid growth in motorization with less corresponding improvement in the road network, traffic management techniques and related transport facilities. While traffic congestion has been managed very well in some developed countries, it has continued to defy solutions in the developing world (Ogunbodede et al, 2003). Ogunbodede (2009), observes that most major Nigeria cities, which includes Akure Township, have been developing without the conventional land use approach. This has generated different urban problems in the form pollution of the environment, transportation problems, insanitary condition and epidemics. This is because the physical growth and development of cities have not been properly managed. It allows conversion of residential uses and other types of buildings to commercial use, street trading, parking and infrastructural facilities, which increases the volume of traffic in such neighborhood. Over the years, the transportation route of Oba Adesida road, Akure along the Oja-Oba (king's market) axis has a lowed the commercial activities along that route to be very efficient serving larger percentage of the Akure populace. However, it is important to note that when the commercial activities of any area rises, the transportation route and facilities are likely to be neglected, which later deteriorate due to over use and lack of maintenance. Most often, coincidence arises from individual commuter's journey during peak hour periods. This type of coincidence, if not well managed, may lead to traffic crisis that makes traveling burdensome in addition to wasting person-hour productive time. In this study, the effects of commercial activities on transportation routes will be examined and possible solutions would be proffered in order to ensure a smooth ride within this commercial centre (Aderamo,1990).

\subsection{Research Question}

This study will make attempt to answer the following questions:

i. What is the level of traffic congestion at Oja-Oba?

ii. Is there any notable relationship between the level of market patronage and traffic congestion in the study area?

iii. Is there any significant relationship between the modes of transit and traffic congestion at Oba Adesida road?

\subsection{Study Area}

Akure South is a Local Government Area in Ondo State Nigeria, which is made up of Akure and Oda town with its headquarters in Akure the State capital (See Fig. 1.1-1.3). Akure is a traditional city and like other traditional Yoruba towns in the country, folklore mentioned that the city was founded by a descendant of Oduduwa, the progenitor of the Yoruba people.The prince left Ile-Ife in search of a place to settle just as many other Yoruba cities were founded by the prince. The heavy royal beads on his neck was to have broken with the beads running off thereby deciphering this must be the place 'Olorun' meaning God wanted him to settle here, hence the name Akun re, meaning beads broken, later became Akure. Akure existed long before the advent of British colonial rule (Wikipedia, 2015). Akure is a medium- sized urban centre and became the provincial headquarter of Ondo province in 1939. It also became the capital city of Ondo State and a Local Government headquarters in 1976. (Wikipedia, 2015). The city's morphology has changed over time to assume its present status with its attendant land use problems, as experienced in similar medium sized urban centres in Nigeria. Its population was estimated to be 112,850 in 1980; 144,544 in 1987, 148,880 in 1988, 153,347 in 1989 
and 157,947 in 1990. The 1991 national population census however, put the population of Akure at 239,124 and its estimated population in 1996 was 269,207.At present, the cityhave a population of approximately 387,082 . The population increase in Akure in the past three decades could be attributed to its administrative functions as the state capital, location of tertiary institutions of learning, discovery of mineral deposits in parts of the state, increased banking and markets activities (commercial) such as Oja Oba meaning king market (See Plate 1).

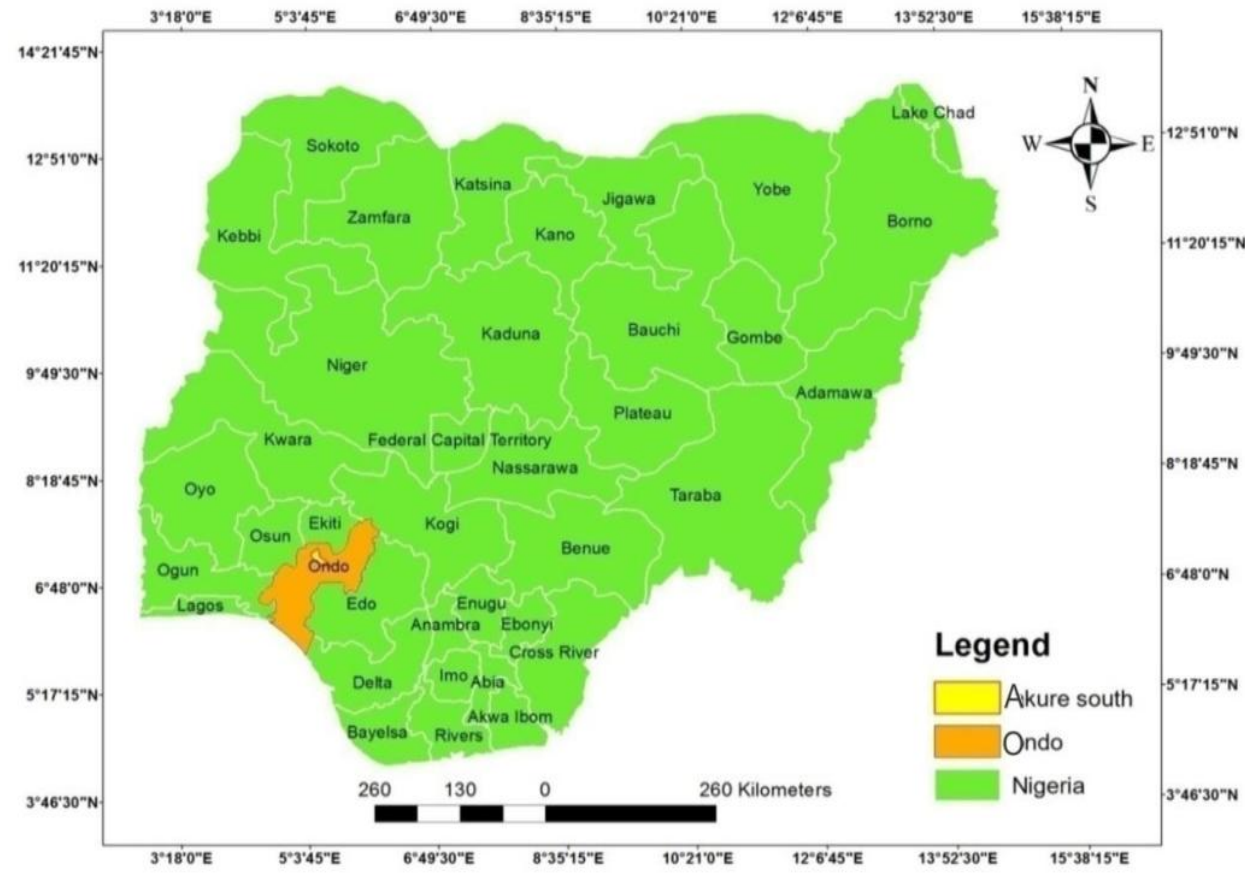

Figure1. 1. Map of Nigeria Showing Ondo State

Source: Google Satellite Imagery, 2016

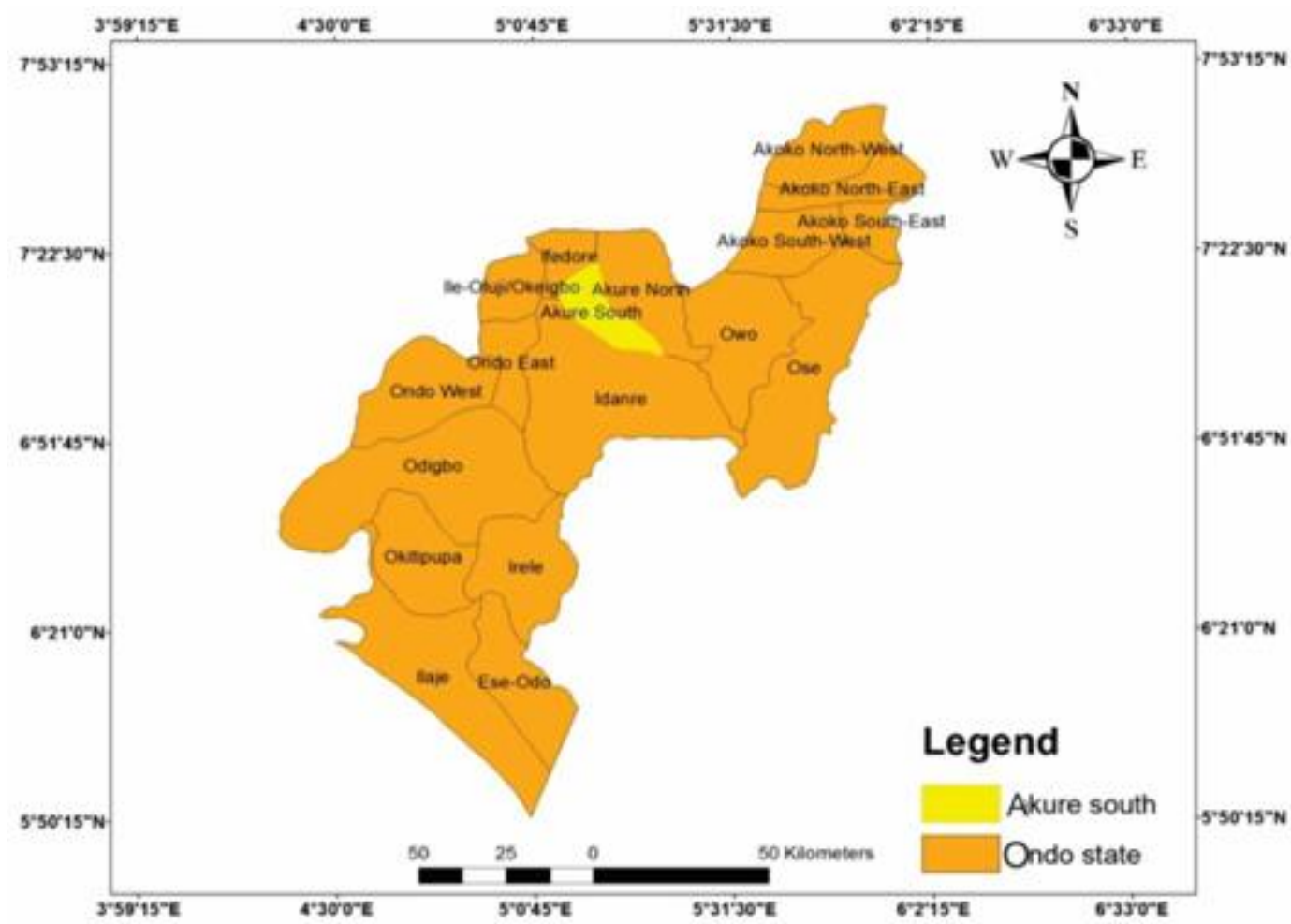

Figure1.2. Map of Ondo State Showing Akure-South Local Government Area

Source: Google Satellite Imagery, 2016 


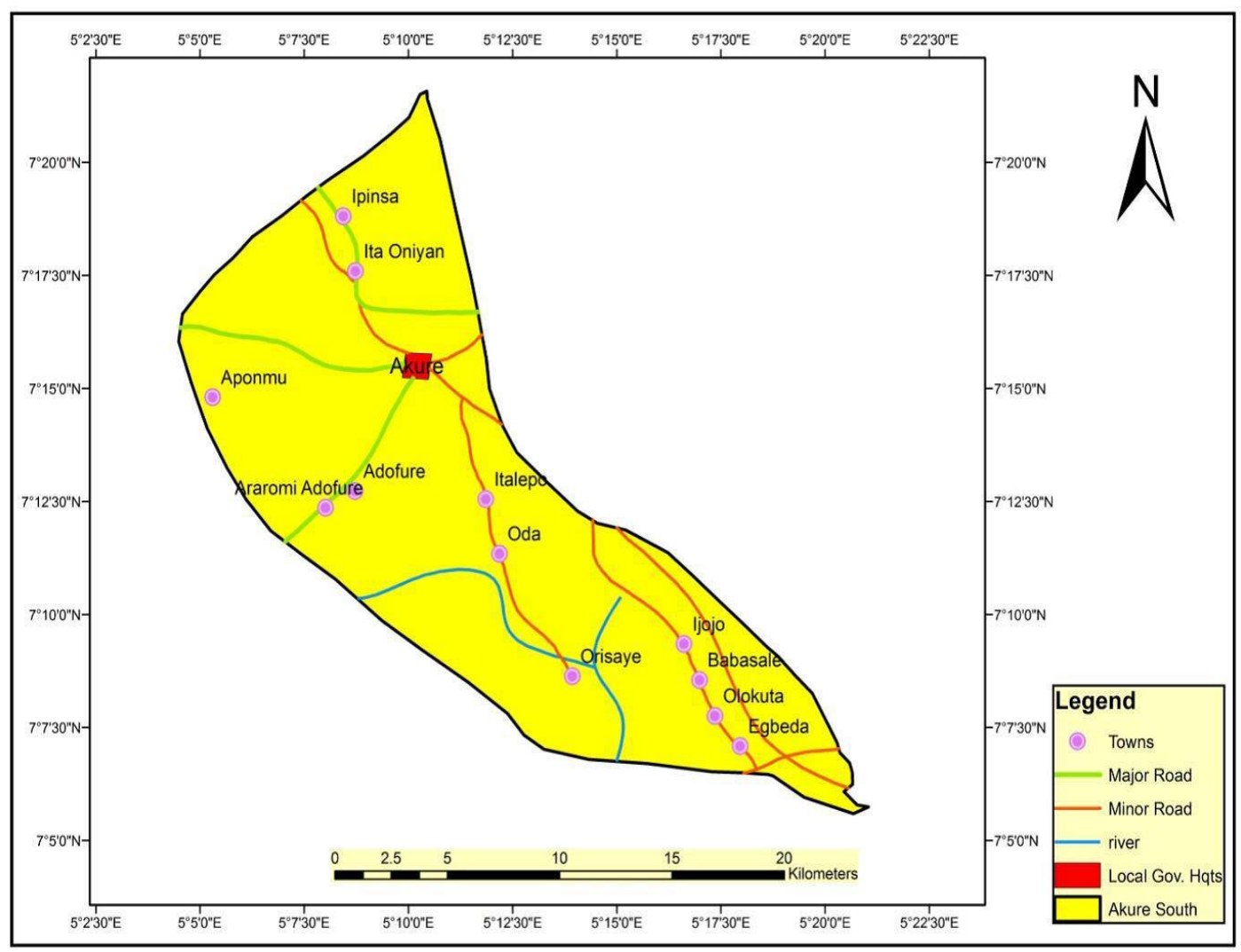

Figure1.3. Map of Akure South Local Government Area

Source: Akure South Local Government Area, 2016

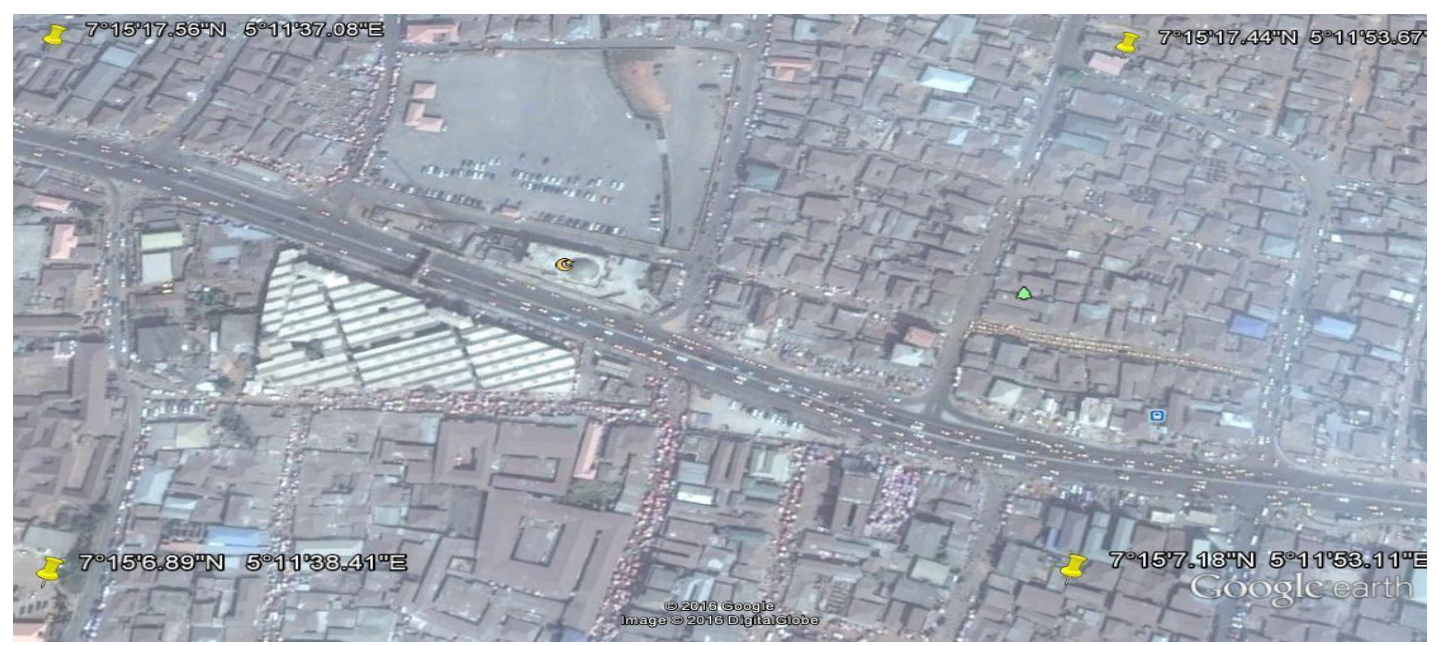

Plate I. Google Imagery of Oja Oba

Source: Google Map, 2016

\section{Literature REVIEW}

Many professionals across the globe have taken interest in studying the linkage between transportation system and City growth or urban development. Okoko, 2006, explained that cities are locational only with arrangement of specialized people and activities designed to maximize transactions. He explains it further that city as an engine of economic development and centre of industry, commerce and administration functions only with efficient systems of transportation. It would be useful at this stage to establish that reciprocal relationship exists between transportation systems and urban land-use as the former determines the intensity and patterns of activity within city. However, transportation plays major role in urban development and on city growth, being a major urban land use element. (Okoko, 2006). The importance of transportation to the economy of nations has been widely recognized. It has been argued that the level of transportation in a country is linked with the level of economic development of that country (Okoko, 2006). It is, however, the 
consensus of many that traffic is a function of land use. For example, a commercial zone attracts workers, shoppers, sellers, schoolchildren and goods. All land use types have the ability to attract traffic and to generate traffic (either passenger traffic or goods traffic) at varying intensities. It promotes the development of various activities that foster its economic development and provides necessary channels of communication and interaction. Litman (2015) reported that transportation and land use planning decisions interacts, that is transport planning decisions affect land use development, and land use conditions affect transport activity (See table 1.1). These relationships are complex, with various interactive effects. He went on to investigates how some land use factors affect transport activity, including vehicle ownership, vehicle travel (vehicle trips and vehicle miles of travel or VMT), mode share (the portion of trips by different modes), active transport (walking and cycling), and therefore impacts on various planning issues such as traffic congestion, infrastructure costs, consumer costs, accident rates, physical fitness, and social equity objectives (Litman, 2015).

\section{Land Use Factor}

Table1.1. Various Land Use Factors That can Affect Travel Behavior and Population Health

\begin{tabular}{|c|c|c|}
\hline Factor & Definition & Mechanisms \\
\hline $\begin{array}{l}\text { Regional } \\
\text { Accessibility }\end{array}$ & $\begin{array}{l}\text { Location relative to regional centres, } \\
\text { jobs or services. }\end{array}$ & $\begin{array}{l}\text { Reduces travel distances } \\
\text { regional destinations } \\
\text { services and jobs). }\end{array}$ \\
\hline Density & $\begin{array}{l}\text { People, jobs or houses per unit of land } \\
\text { area (acre, hectare, square mile or } \\
\text { kilometer). }\end{array}$ & $\begin{array}{l}\text { Reduces travel distances. Increases } \\
\text { destinations within walking and } \\
\text { cycling distances. Increases } \\
\text { sidewalk, path and public transit } \\
\text { efficiencies. Increases vehicle } \\
\text { congestion and parking costs. }\end{array}$ \\
\hline Mix & $\begin{array}{l}\text { Proximity of different land uses } \\
\text { (residential, commercial, institutional, } \\
\text { etc.).Sometimes described as } \\
\text { bs/ housing balance, the ratio of jobs } \\
\text { and residents in an area. }\end{array}$ & $\begin{array}{l}\text { Reduces travel distances between } \\
\text { local destinations (homes, services } \\
\text { and jobs). Increases the portion of } \\
\text { estimations within walking and } \\
\text { cycling distances. } \\
\text { Provides agglomeration } \\
\text { efficiencies and increases public } \\
\text { transit service efficiency. }\end{array}$ \\
\hline $\begin{array}{l}\text { Centeredness } \\
\text { (Centricity) }\end{array}$ & $\begin{array}{l}\text { Portion of jobs, commercial and other } \\
\text { activities in major activity centres. }\end{array}$ & $\begin{array}{l}\text { Provides agglomeration } \\
\text { efficiencies and increases public } \\
\text { transit service efficiency. }\end{array}$ \\
\hline Connectivity & $\begin{array}{l}\text { Degree that roads and paths are } \\
\text { connected and allow direct travel } \\
\text { between destinations. }\end{array}$ & $\begin{array}{l}\text { Reduces travel distances. Reduces } \\
\text { congestion delays. Increases the } \\
\text { portion of destinations within } \\
\text { walking and cycling distances. }\end{array}$ \\
\hline $\begin{array}{l}\text { Roadway } \\
\text { design and } \\
\text { management }\end{array}$ & $\begin{array}{l}\text { Scale and design of streets, to control } \\
\text { traffic speeds, support different modes, } \\
\text { and enhance the street environment. }\end{array}$ & $\begin{array}{l}\text { Improves walking, cycling and } \\
\text { public transit travel. May improve } \\
\text { local environments so people stay } \\
\text { in their neighborhoods more. }\end{array}$ \\
\hline $\begin{array}{l}\text { Parking supply and } \\
\text { management }\end{array}$ & $\begin{array}{l}\text { Number of parking spaces per building } \\
\text { unit or hectare, and the degree to which } \\
\text { they are priced and regulated for } \\
\text { efficiency. }\end{array}$ & $\begin{array}{l}\text { Increased parking supply } \\
\text { disperses destinations, reduces } \\
\text { walkability, and reduces the costs } \\
\text { of driving. }\end{array}$ \\
\hline transport & $\begin{array}{l}\text { Quantity and quality of sidewalks, } \\
\text { crosswalks, paths, bike lanes, bike } \\
\text { parking, pedestrian security and } \\
\text { amenities. }\end{array}$ & $\begin{array}{l}\text { Improves pedestrian and bicycle } \\
\text { travel, and therefore public transit } \\
\text { access. Encourages more local } \\
\text { activities. }\end{array}$ \\
\hline Transit accessibility & $\begin{array}{l}\text { The degree to which destinations are } \\
\text { accessible by high quality public transit. }\end{array}$ & $\begin{array}{l}\text { Improves transit access and } \\
\text { supports other accessibility } \\
\text { improvements. }\end{array}$ \\
\hline $\begin{array}{l}\text { Site design parking } \\
\text { facilities Mobility } \\
\text { Management }\end{array}$ & $\begin{array}{l}\text { The layout and design of buildings and } \\
\text { Various strategies that encourage use of } \\
\text { alternative modes. }\end{array}$ & $\begin{array}{l}\text { Improves and encourages use of } \\
\text { alternative }\end{array}$ \\
\hline
\end{tabular}




\subsection{Conceptual Framework}

Transportation planning is the art and science of providing and managing transportation facilities in a manner that ensures an efficient movement of commuters and freights within a given spatial entity (Okoko, 2006). Transportation is a process that involves the movement of commuters' goods and services from a given point of origin to a specific destination. (Okoko, 2006). Transport planning plays fundamental role in the state region or community vision of possible strategies, an evaluation process that encompasses diverse viewpoint; the collaborative participation of relevant transportation related agencies and organization and open timely and planning repairing public involvement this transportation planning is involved with the evaluation, assessment, design and sitting of transport facilities (general streets, highways and public transport lanes) transportation planning is expressed as a co-operative process designed to foster involvement by all users of the system, such as the business community groups, environmental organization, the traveling public, freight operators and the general public, through a proactive participation process. Using the framework of transportation planning, transport expert otherwise known as transport planner should perform the following key notes.

a. Take account of the social economic of the area of jurisdiction

b. Understand and create transport policies strategies and plans that contribute to meeting the social, economic and environmental needs.

c. Design the necessary transport projects system and services.

d. Understand the commercial aspects of operating transport systems and services. e) Know about and apply the relevant tools and techniques.

\subsubsection{Transportation and its Impact in Nigeria}

\section{Evolution of Road Transportation in Nigeria}

The earliest form of land transport in Nigeria is human patronage. From the primordial times, hunters carried home the animals they killed, when a family moved, their possessions had to be carried by hand or on backs; people carried their goods to nearby or distance markets on foot (Oyinloye, et al, 2012). As a result of these daily activities the foot path began to winding and expand to contain more than one patronage which result to road transportation. Road connect areas of surplus goods and services to areas where there is a deficit of goods and services. Road network began to exist in Nigeria and they were narrow and winding, being simply meant to facilitate the evacuation of agricultural produce from interior to the ports for exports in addition to serving as links between scattered human settlements thus permitting ease of administration.

\section{Classification of Road in Nigeria}

According to Okoko (2006), Nigeria's roads were classified into three group namely Truck Roads A, Truck Roads B and Truck Road C. They serve as the framework or skeleton of any town plan and provide the conduits and veins for the influx and efflux of commuters, freights and ideas. Truck A Roads: Truck A roads are the major roads that provide links between the federal capital and state capital and also between the state capitals and other large town and seaports.

They also provide international links between important towns in neighboring countries. They are usually in form of a grid framework on which the rest of the road system is built e.g. Port-HarcourtAba-Enugu road and Lagos-Ibadan-Ife-Ilesa road etc. since this category of roads of great importance to the economy of the nation; they are usually constructed and maintained by Federal Government.

Truck B Roads: This category of road provides the link between local government headquarters and other large towns. In the majority of cases, this class of road is constructed and maintained by the state 21 government. Sometimes, some other local authorities with some assistance from the state government can construct this category of road.

Truck C Roads: Truck C roads normally form a network of roads that connect small towns and villages with one another. It also provides a link between these smaller towns, villages with bigger towns in the community. Truck $\mathrm{C}$ roads therefore serve as feeder roads to the truck A and Truck B roads. They are mostly constructed and maintained by local governments. Sometimes with great from the state government. 
Mode of Transportation

Each principal means of transportation varies widely in its form and in the arrangement of its component parts. A consequence is that different modes of transport service different traffic densities, which in turn affect network structure. These differences reflect the types of traffic that each mode was designed to carry and thus, mode of transportation is examined with return to;

A. Their capacity for particular type of passenger and freight

B. Their ability to attract various segments of the market in terms of service quality and reliability

C. Mode flexibility i.e. the extent to which a transport system can adapt to changing market.

\section{RESEARCH METHODOLOGY}

Research methodology can be described as the various steps, guidelines and measures by which data for a particular study are sourced, collected, processed, and analyzed, with a view of coming up with findings that will help in achieving research goal (Kothari, 2004). This chapter is therefore concerned with the explanation of the essentials of the research process and these include data collection techniques, sampling frame, sampling size, questionnaire design, as well as data analysis and presentation. In this study, data was collected and analysed based on the objectives of the study.

\subsection{Research Design}

A research design is usually a set of procedure that a researcher has to follow in the process of collecting, analyzing and interpreting this data. It highlights the specific problems that the researcher studied, and by implication the justification for the study (Okoko, 2006). The research questions were based on information about respondents and other information as regards the viewed problem.

\subsection{Research Population}

Research population is the audience that a research instrument is set to address (Okoko, 2006). According to the 2006 census count by National Population Commission, the population of Akure South LGA was 353,211 . A population projection was adopted in order to determine the present population of the study area. According to (CIA World fact book, 2013) Nigeria population growth rate is put at $2.553 \%$ and the projection formula by (Mehta, 1996) is $\mathrm{Pt}=\mathrm{Po}(1+(\mathrm{R}) \mathrm{n})$ Where;

$\mathrm{Pt}=$ Projected population, $\mathrm{Po}=$ Base year population

$\mathrm{R}=$ Annual growth rate $(2.553 \%)$

$\mathrm{n}=$ Time interval

Therefore,

Po $=353,211$

$\mathrm{n}=2016-2006=10$

$\mathrm{R}=2.553 \%=0.02553$

$\mathrm{Pt}=353211(1+(0.02553) 10) \mathrm{Pt}=353211(1.2553)=443,385$

Hence, the projected population of Akure South LGA for 2016 was 443,385 people.

\subsection{Sampling Frame}

A sampling frame is to provide a means for choosing members of the target population that are to be interviewed in the survey (Kothari, 2004). It involves the identification and aggregation of the study population units and the investigation structure. For the purpose of this research, three markets were deeply accessed in order to answer every necessary question. Reason for selecting these areas was the high patronage in these market places and varieties in item sold. Research findings revealed that various kinds of commercial activities existed in the study area. Examples of the existing commercial activities are; boutique, grocery stores (foodstuffs, provisions etc.), phone repair shops, bank with ATM machines. Other commercial activities located along the transport route in the Oja-Oba market are; computer typesetting and photocopying, passport photographing, commercial motorcycling, hawking, street trading, wheel barrow/truck pushing. 
This research identified three (3) study groups of investigation at the (Oja-Oba) market. The three categories investigated in the frame were; market traders (sellers), buyers and road users (private and public drivers).

Table3.1. Sample Frame of the Market Places and Sale Stalls

\begin{tabular}{|l|l|l|l|}
\hline S/No & Market Places & Location/Road & Sales Stalls (stall owners) \\
\hline 1 & Oja Oshodi Road & Oja Oshodi/Oba Adesida & 50 \\
\hline 2 & Erekesan market & Oba Adesida Road & 1,020 \\
\hline 3 & Olukayode shopping complex & Oba Adesida Road & 80 \\
\hline Total & \multicolumn{2}{|l|}{1,150} \\
\hline
\end{tabular}

Source: Author's field survey, 2016

\subsection{Sample Size}

The sample size usually depends on the population size to be sampled. In other words, the sample size is a function of the total population and the purpose of the research. The projected population of Akure South LGA for 2016 was 443,385 people. Kothari(2004), emphasized that sample size depends on the variability of the sampling population. The following criteria was considered to identify which market places was selected for the study: the geographical location, periodicity (daily or weekly) of the market, Central Business District function (location within the CBD), and traffic influence. This study is peculiar for some obvious reasons; the number of stalls in the market mostly did not reflect the number of traders (sellers and buyers) in the market; for instance, in most cases, two or more traders shared the same stall, while others displayed their wares on available spaces that were not allotted to them. It should be noted at this point that the population of traders could not be ascertained because, there were some mobile traders (hawkers) in the market as well as their customers, which could not be differentiated in most cases.

However, for the purpose of this study, the number of stalls was used to identify the legitimate sellers in the allotted market stalls. According to the table 3.1 above, the total population of the sampled market stalls (i.e. the number of stall owners) in the market were 1,150 stalls (See table 3.2). A percentage of $9 \%$ was considered reasonable for the total population size, which gives a total sample size of 100 cases that represented the stalls that was accessed. The tables below show the selected market place and copies of questionnaires administered.

Table3.2. Sample Size of the Market Places and Questionnaire Administered to the Stalls

\begin{tabular}{|l|l|l|l|}
\hline S/No & Market places & No of stall owners & $9 \%$ Questionnaire \\
\hline 1 & Oja Oshodi & 50 & 4 \\
\hline 2 & Erekesan market & 1020 & 89 \\
\hline 3 & Olukayode shopping complex & 80 & 7 \\
\hline Total & & 1150 & 100 \\
\hline
\end{tabular}

Source: Author's ield survey, 2016

Secondly, the size of the buyers were a function of the total sample population of Akure South LGA. It can be deduced that an average of one person per household visits the market place at a time. The projected population of Akure South LGA for 2016 was 443,385 people, dividing the projected population by seven (7) which is the average number of a household size as stated by Ogunbodede (2009) to determine the number of houses in Akure South LGA; it arrives at 63,340 houses. Questionnaires were administered to the buyers at the sellers' stalls since this was the only point where they could be easily accessed. Therefore, $0.16 \%$ of the population was sampled, and because of this, one hundred (100) questionnaires were administered in the areas, which were allocated to each in proportion to the spread and population size of the sellers (See table 3.3).

Table3.3. Sample size of the market places and questionnaire administered to the buyers

\begin{tabular}{|l|l|l|}
\hline S/No & Market Places & $0.16 \%$ Questionnaire \\
\hline 1 & Oja Oshodi & 4 \\
\hline 2 & Erekesan market & 89 \\
\hline 3 & Olukayode shopping complex & 7 \\
\hline & Total & 100 \\
\hline
\end{tabular}

Source: Author's Field Survey, 2016 
Finally, the number of vehicles that visit the market place was investigated through a traffic assignment census to be conducted manually because not all vehicles visit the market place at the same time. One major car park around the market place was the "democracy park", which was assessed as regarding this research. According to the resource at the park, an average of 300 cars park at the democracy park (See table 3.4). A sample size of $16 \%$ of the cars parked was accessed in order to capture every possible opinion of the utilizers in respect to the commercial activities against the road; because of this, 50 questionnaires were administered at the car park (Democracy Park).

Table3.4. Sample size of the car park and questionnaires administered to the drivers

\begin{tabular}{|l|l|l|l|}
\hline S/No & Location & No of cars & $16 \%$ Questionnaire \\
\hline 1 & Democracy park & 300 & 50 \\
\hline
\end{tabular}

Source: Author's Field Survey, 2016

In total, 250 questionnaires were administered for the purpose of this research. 100 questionnaires for the sellers and stall owners, 100 questionnaires for the buyers/visitors and 50 questionnaires for the drivers (See table 3.5).

Table3.5. Number of Questionnaires administered to the three categories

\begin{tabular}{|l|l|l|}
\hline S/No & Categories & No of Questionnaires \\
\hline 1 & Sellers & 100 \\
\hline 2 & Buyers & 100 \\
\hline 3 & Drivers & 50 \\
\hline Total & & 250 \\
\hline
\end{tabular}

Source: Author's Field Survey, 2016

\subsection{Sampling Technique}

There are different sampling techniques, some of which are; stratified sampling, simple random sampling technique and quota sampling technique. However, for the purpose of this research work, the simple random sampling technique was adopted, a kind of probabilistic sampling whereby elements of the sample size would be selected randomly. It can be further said that the choice for this sampling technique goes a long way to eliminate bias in the choice of respondents.

\subsection{Data Collection Instrument}

The data collection instruments that was used for this research include Field observation, Oral interview, Photographs of features, Questionnaire administration and Secondary source of data collection.

Field Observation is the recording of behavioural patterns of people, objects and occurrences without questioning or having verbal communication with the people. It helps in drawing inferences from what has been observed on site in the course of observation process (Kothari, 2004). Oral Interview refers to an unconstructed and open-ended answer a respondent is allowed to give in response to a question. Photographs of Features gives a clear concise representation of features in the study area. Questionnaire construction consisting of standardized questions was used to collect information in the study area. The questionnaire prepared for the research survey was drafted in a recorded format whereby the respondents filled the questionnaire by ticking among the options provided (Okoko, 2006).

\subsubsection{Data Types and Sources}

Research work cannot be done without due reference to sources of information. This research relies on two major sources of data, which are:

\section{i. Primary source \\ ii. Secondary source}

\subsubsection{Primary Source}

Primary source of data refers to the sources from the personal effort made by the researcher with that of his field assistance to collect data and information directly from the targeted population in 
connection with the study (Kothari, 2004). This is done by preparing a well-structured questionnaire. Therefore, the data collected was collated, analysed and statistical or qualitative analysis was carried out on the data as to know the relationship between variables and draw logical conclusion that attract suitable recommendation.

\subsubsection{Secondary Source}

This refers to the data that were gotten from academic sources, which include textbooks, journal articles, conference papers, publications on various aspects of transport planning, internet, National Population Commission and other relevant thesis. In other words, they were data gotten from other scholars' work or researches.

\subsection{Procedure for Data Collection}

The field assistance administered the questionnaires to the respondents in the study area. Data was collected at specific period and places (the stalls in the market place and the motor park) to ensure that targeted responses were met.

\subsection{Method of Data Analysis}

The data obtained from the questionnaires was processed using the Statistical Packages for the Social Science (SPSS) for descriptive statistical analysis. The relationships between variables are shown using descriptive method of data presentation, that is; tables and charts.

\section{RESULT OF FINDINGS}

\subsection{Presentation and Analysis of Data According to Research Question and Hypothesis}

The level of traffic congestion results when traffic demand is great enough that interaction between vehicles slows the speed of the traffic stream streams. The opinion of respondents on the condition of traffic congestion in Oja Oba market was analyzed and reported. About 25\% of the sellers reported the traffic as "not strong", $13 \%$ of the respondents showed "fairly strong", and $17 \%$ of the respondents showed the "average" while $45 \%$ of the respondents said the traffic was "strong". The buyer gave almost about the same statistics; $8 \%$ revealed "not strong", $17 \%$ revealed "fairly strong", $24 \%$ of the respondents agreed that the traffic was "average", while 50\% suggested "strong". Moreover, the drivers gave different opinions to the situation of traffic congestion in the area probably because they have more experience driving. About $8 \%$ agreed it to be "fairly strong", $28 \%$ revealed it is on the "average", while $64 \%$ revealed that the traffic is "strong". The summary of this analysis showed that a higher percentage of the three categories of respondent agreed that the traffic congestion along the $\mathrm{Oja}$ Oba market is "strong" (See plate 1 and 2).

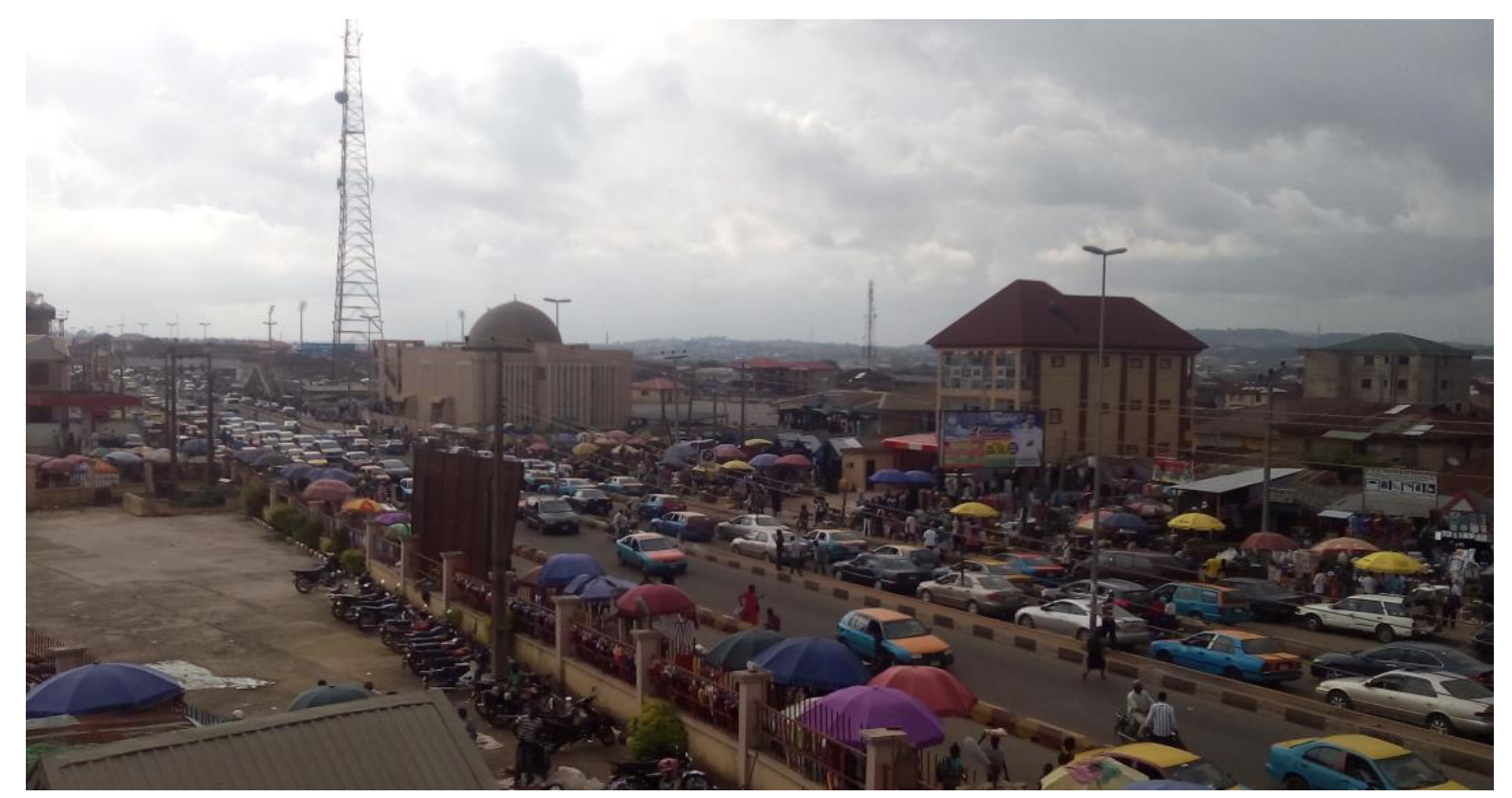

Plate1. Oja Oba during a Traffic Situation I

Source: Author's Field Survey, 2016 
Effects of Commercial Activities on Transportation Route in Urban Centres in Nigeria: A Case Study of Oba Adesida Road, Akure

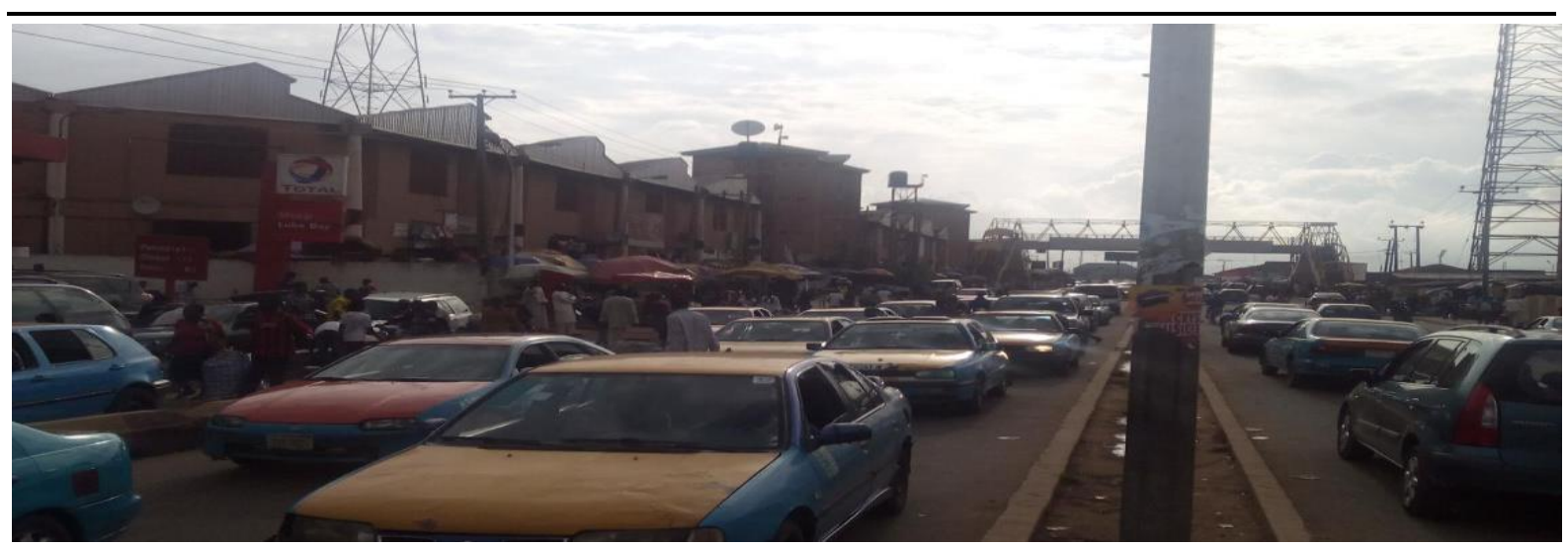

Plate2. Oja Oba during a Traffic Situation II

Source: Author's Field Survey, 2016

\subsubsection{Use of Cars to Owners (Sellers and Buyers)}

From the analysis of the data, the analysis showed the same percentage with the car ownership. The $45 \%$ of the seller revealed they used their cars for private use while the remaining $55 \%$ did not respond because they did not own a car. The buyers show $42 \%$ of private car used while $58 \%$ of the respondents did not respond because they did not own a car. From the data analysed, it revealed that none of the respondents used their car for commercial purpose.

\subsubsection{Rate of Visitation to the Market}

This analysis showed how often the respondents visit the market place. The sellers are the set of people who often visit the market place simply because it is their place of business. From the data analysed, it revealed that $39 \%$ of the sellers visited the market about four to five times weekly, while $61 \%$ of the respondents visited the market six to seven times weekly that is almost every day of the week. The buyer respondents revealed that $45 \%$ visited once in a week, $53 \%$ of the respondents visits two to three time a week while $2 \%$ visits four to five times every week. The driver respondents showed quite a different pattern of visit to the market possibly because they have a vehicle, which they use to facilitate their movement. These statistics revealed that $8 \%$ of the respondents visited the market once a week, $60 \%$ visit two to three time weekly while $32 \%$ visited the market four to five times weekly. This showed that ownership of a vehicle mostly influences travelling because it is time managing and easy. Apart from the sellers who come to trade every day, the buyers and drivers mostly visited the market between 3-4 days. This implies that there will always be more people in the market, which leads to congestion at the rush hour (See plate 3).

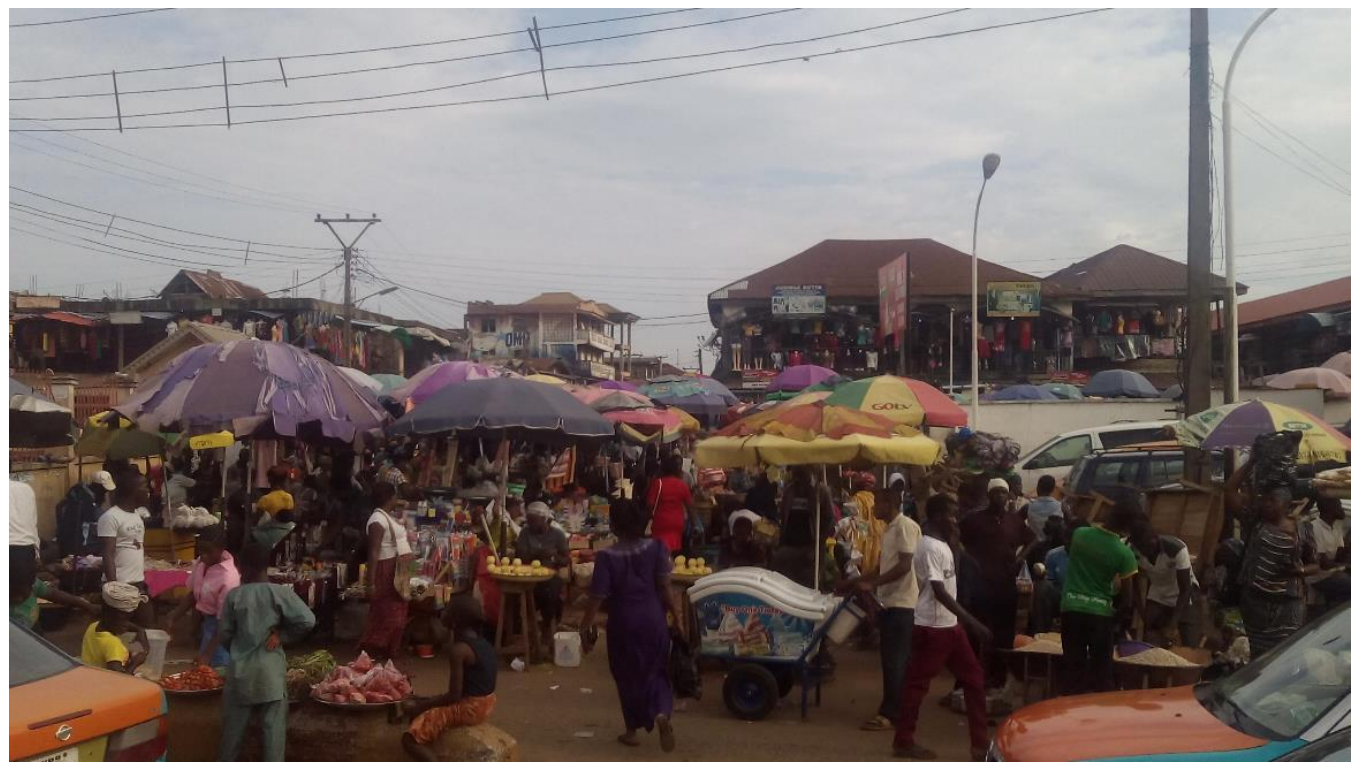

Plate3. People patronizing Oja Oba market

Source: Author's Field Survey, 2016 


\subsubsection{Mode of Transportation of Respondents (Sellers and Buyer)}

According to the analysis showed the means of transportation of buyers and sellers at the market are as follow; about $24 \%$ of the sellers used their private car, $9 \%$ of the respondents used public bus, about $59 \%$ of the respondents boarded a taxi while $8 \%$ used the motorcycle as a means of getting to the market. The buyers' respondents show that $41 \%$ used their private car while $59 \%$ boarded taxi to get to the market. From this analysis, it explains that taxi is the most commonly used means of transportation in Akure.

\subsubsection{Correlation Analysis of the visitation to market and traffic congestion}

The result of the correlation analysis of the modes of transit and traffic congestion in Oja -Oba is presented in tables 4.1 and 4.2 below. Based on the scale of measurement of the modes transit and traffic congestion variables, spearman's rho correlation and chi-square tests were conducted on the following variables: Traffic congestion (TRAF CONG), Rate of Market Visitation (VISIT TO MARKET).

Table4.1. Results of Relationship between Rate of Visitation and Traffic Congestion Variables

\begin{tabular}{|l|l|l|}
\hline Rate of visitation to Market & Spearman's rho & \\
\hline & TRAF CONG & \\
\hline TRAF CONG & 1.000 & 0.263 \\
\hline VISIT TO MARKET & & 1.000 \\
\hline
\end{tabular}

Source: Author's Fieldwork, 2016

Table 4.2 presents the coefficients of relationship between the rate of market visitation and traffic congestion at Oja Oba. A spearman's rho correlation test conducted showed that the relationship between traffic congestion and market visitation accounted for $\mathrm{rs}=0.263$ statistically significant at $\mathrm{p}<0.05$, such that the more market visitation increases, the higher the traffic congestion.

Table4.2. Chi Square Cross-Tabulation Test Results between Mode of Transit and Traffic Congestion

\begin{tabular}{|l|l|l|l|}
\hline Chi-Square Test & Value & df & P-Value \\
\hline & & & \\
\hline Pearson Chi-Square & $36.403 \mathrm{a}$ & 8 & 0.000 \\
\hline Likelihood Ratio & 43.202 & 8 & 0.000 \\
\hline Linear-by-Linear Association & 11.535 & 1 & 0.001 \\
\hline N of Valid Cases & 100 & & \\
\hline
\end{tabular}

a. 9 cells $(60.0 \%)$ have expected count less than 5. The minimum expected count is .02.

Source: Author's Fieldwork, 2016

\subsubsection{Correlation Analysis of the mode of transit and traffic congestion in Oja Oba}

The result of the correlation analysis of the modes of transit and traffic congestion in Oja- Oba is presented in tables 4.3 and 4.4 below. Based on the scale of measurement of the modes transit and traffic congestion variables, spearman's rho correlation and chi-square tests were conducted on the following variables: Traffic congestion (TRAF CONG), Car Usage (CAR USAGE),Mode Transportation (MODE OF TRANS).

Table4.3. Results of Relationship between Modes of Transit and Traffic Congestion Variables

$$
\text { Traffic Congestion Variables Spearman's Rho Correlation Test }
$$

\begin{tabular}{|c|c|c|}
\hline TRAF CONG & CAR USAGE & MODE OF TRANS \\
\hline TRAF CONG & 1.000 & -0.166 \\
\hline CAR USAGE & & 1.000 \\
\hline MODE OF TR & & \\
\hline
\end{tabular}

Source: Author's Fieldwork, 2016 
Table 4.3 presents the coefficients of relationship between modes of transit and traffic congestion at Oja Oba. A spearman's rho correlation test conducted showed that the relations hip between car usage and mode of transportation accounted for $r s=0.563$ statistically significant at $p<0.05$, such that the more the use of a particular mode of transportation, the higher the use of cars by the owners.

Table4.4. Chi Square Cross-Tabulation Test Results between Mode of Transit and Traffic Congestion

\begin{tabular}{|l|l|l|l|}
\hline Chi-Square Test & Value & df & p-value \\
\hline Pearson Chi-Square & $13.812 \mathrm{a}$ & 4 & 0.008 \\
\hline Likelihood Ratio & 17.429 & 4 & 0.002 \\
\hline Linear-by-Linear Association & 10.820 & 1 & 0.001 \\
\hline N of Valid Cases & 100 & & \\
\hline
\end{tabular}

${ }^{a} 4$ cells $(40.0 \%)$ have expected count less than 5. The minimum expected count is .41

Source: Author's Fieldwork, 2016

The Chi-Square test in Table 4.4 reveals a statistically significant relationship between the Mode of Transit and Traffic Congestion at Oja Oba. The null hypothesis (H03) is therefore rejected.

\subsection{Analysis of Other Data}

\subsubsection{Customers Attended to by the Sellers (Sellers)}

This analysis reveals the number of customers attended to by the sellers; it also showed the level of patronage in the market. The table 4.5 below showed that $42 \%$ of the sellers attended to less than 50 customers per day, about $29 \%$ of the respondents attended to about 51 to 100customers, $10 \%$ attended to about 101 to 150 customers, $3 \%$ attended to 151 to 200 customers while $16 \%$ of the sellers attended to over 200 customers. The volume of customers attended to vary according to the type of goods sold by the sellers. For example, a boutique would apparently attend to more customers than an electronic store, or a phone repair shop (See table 4.5).

Table4.5. Customers Attended to Per Day

\begin{tabular}{|l|l|l|}
\hline Number of Customers & Frequency & Percent (\%) \\
\hline Below 50 & 42 & 42.0 \\
\hline $51-100$ & 29 & 29.0 \\
\hline $101-150$ & 10 & 10.0 \\
\hline $151-200$ & 3 & 3.0 \\
\hline Above 200 & 16 & 16.0 \\
\hline Total & 100 & 100.0 \\
\hline
\end{tabular}

Source: Author's Field Survey, 2016

\subsubsection{Patronage of Hawkers (Buyers)}

This analysis based on the buyers' responses in figure 4.1, reveals the level of patronage of hawkers; it showed that $63 \%$ of the respondents patronized hawkers while $37 \%$ did not patronize hawkers. This implies that hawking is very much encouraged in the market. For the fact that hawkers do not have static position for selling, they are required to stop and attend to their customers on the roadside, which in turn affects other road users on the same road at the same time (See plate 4).

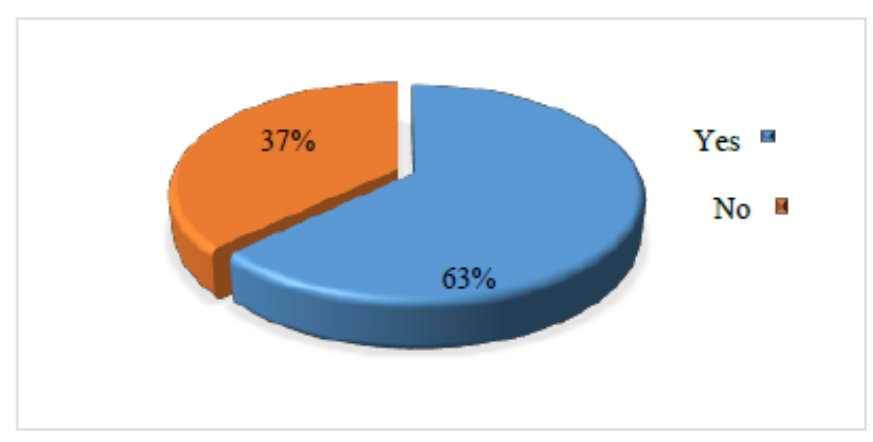

Figure4.1. Patronage of Hawkers

Source: Author's Field Survey, 2016 


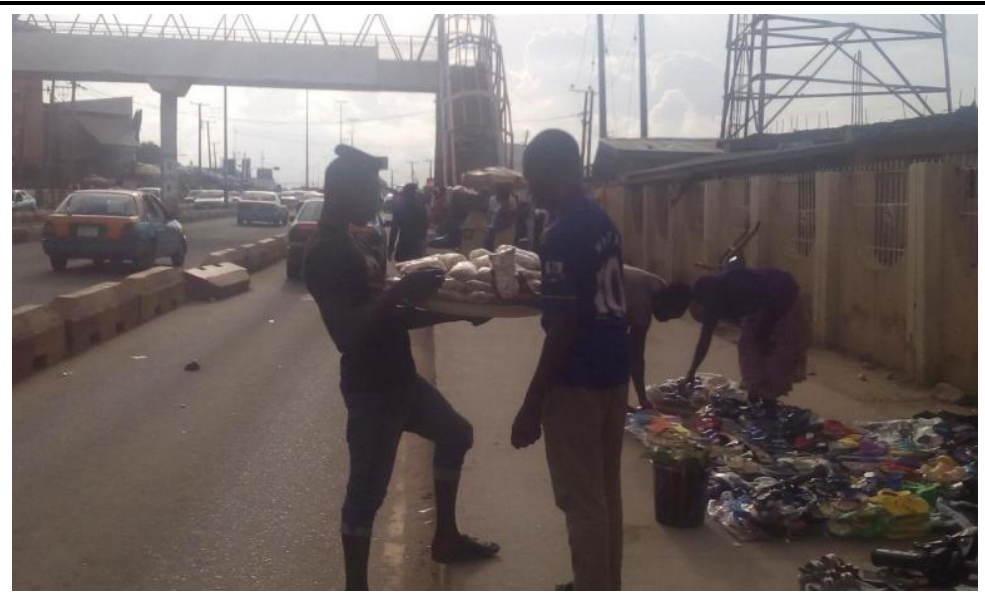

Plate4. Hawker Attending to a Customer

Source: Author's Field Survey, 2016

\subsubsection{Patronage of Wheelbarrow pushers (Buyers)}

This analysis was based on the buyers' responses, which reveals the level of patronage of wheelbarrow, which showed that $75 \%$ of the buyers patronized the wheelbarrow pushers while $25 \%$ did not patronize them. The patronage of wheelbarrow depends on the quantity of goods bought, and there is need to move from where it is bought to the vehicle that will convey it to its final destination (See plate 5)
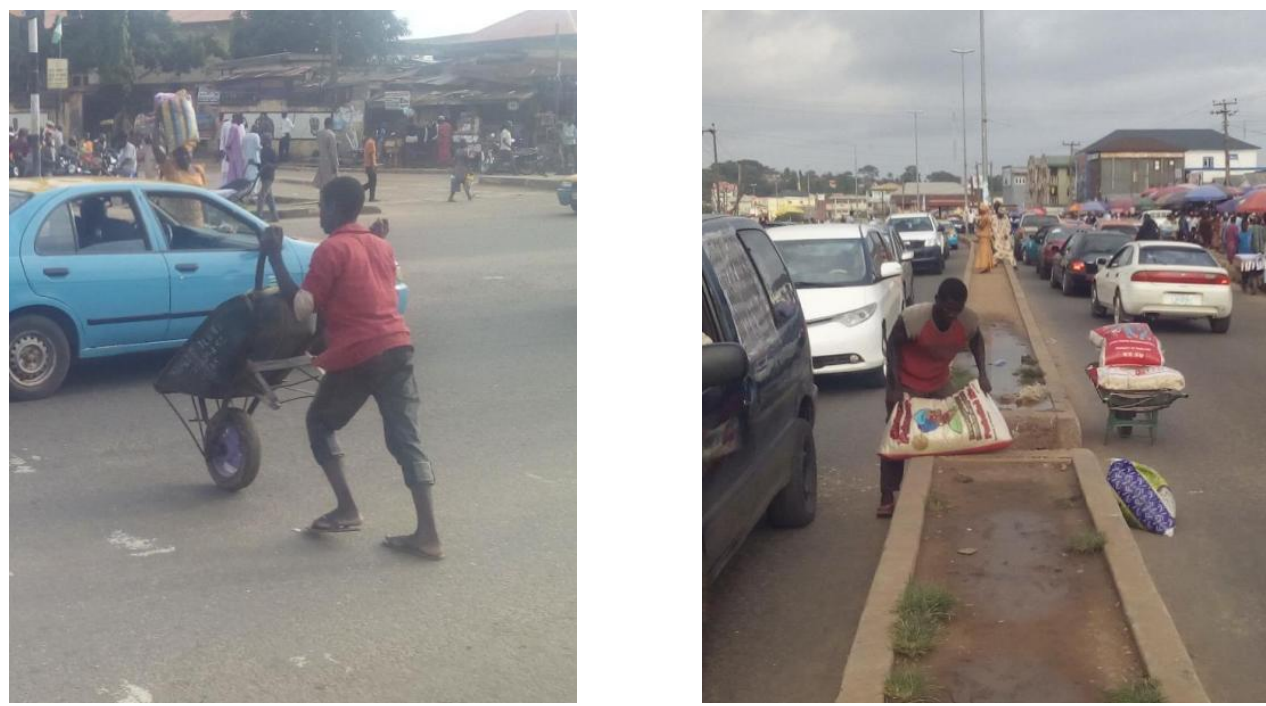

Plate5. Wheelbarrow Pushers Crossing the Road during Traffic

Source: Author's Field Survey, 2016

4.2.4. Means of Conveying Good (Buyers)

According to the analysis gotten from the table 4.6 below, it reveals that all the respondents interviewed use car for the means of conveying the goods bought at the market to their respective homes. This analysis was influenced mostly by the fact that the commonest means of transportation in Akure was car, which could be private or public.

Table4.6. Means of Conveying Goods

\begin{tabular}{|l|l|l|}
\hline Means & Frequency & Percent \\
\hline Motorcycle & 0 & 0.0 \\
\hline Car & 100 & 100.0 \\
\hline Bus & 0 & 0.0 \\
\hline Lorry & 0 & 0.0 \\
\hline Foot & 0 & 0.0 \\
\hline Total & 100 & 100 \\
\hline
\end{tabular}

Source: Author's Field Survey, 2016 
Effects of Commercial Activities on Transportation Route in Urban Centres in Nigeria: A Case Study of Oba Adesida Road, Akure

4.2.5. Length of Stay in Traffic (Drivers)

This analysis reveals the drivers' responses to the time spent in traffic in table 4.7 ; it showed that $28 \%$ of the respondents spent less than $10 \mathrm{mins}$ in traffic, $50 \%$ spent about 10 to $20 \mathrm{mins}$, and about $22 \%$ of the respondents spent 21 to 30mins in traffic. This reveals that the traffic in the study area is strong (i.e. movement is very slow and sluggish) due to the activities encountered on the road.

Table4.7. Length of Stay in Traffic

\begin{tabular}{|l|l|l|}
\hline Time in Traffic & Frequency & Percentage \\
\hline Less than 10mins & 14 & 28.0 \\
\hline $10-20 \mathrm{mins}$ & 25 & 50.0 \\
\hline $21-30 \mathrm{mins}$ & 11 & 22.0 \\
\hline 31-40mins & 0 & 0.0 \\
\hline Over 40mins & 0 & 0.0 \\
\hline Total & 50 & 100.0 \\
\hline
\end{tabular}

Source: Author's Field Survey,2016

\subsubsection{Causes of Traffic Congestion}

Traffic congestion expresses a condition on road network that occurs as the use increases. It is known by slow speed, vehicular queue, and longer time of trip. Some of the causes recognized in this study were; traffic rule violation, on-street parking, on-street trading and low road space. The analysis in table 4.8 below showed the opinion of the drivers on the cause of traffic congestion. About $24 \%$ of the respondents revealed that "traffic rule violation" was the cause, $30 \%$ of the respondents went for "on street trading", and 38\% went for "on street parking" while $4 \%$ agreed that "low road space" was the cause of traffic congestion. It implies that on-street parking and on-street trading are the major causes of traffic (See plate 6).

Table4.8. Causes of Traffic Congestion

\begin{tabular}{|l|l|l|}
\hline Causes of traffic congestion & Frequency & Percent \\
\hline Traffic rule violation & 12 & 24.0 \\
\hline On-street trading & 15 & 30.0 \\
\hline On-street parking & 19 & 38.0 \\
\hline Low road space & 4 & 8.0 \\
\hline Total & 50 & 100.0 \\
\hline
\end{tabular}

Source: Author's field survey, 2016

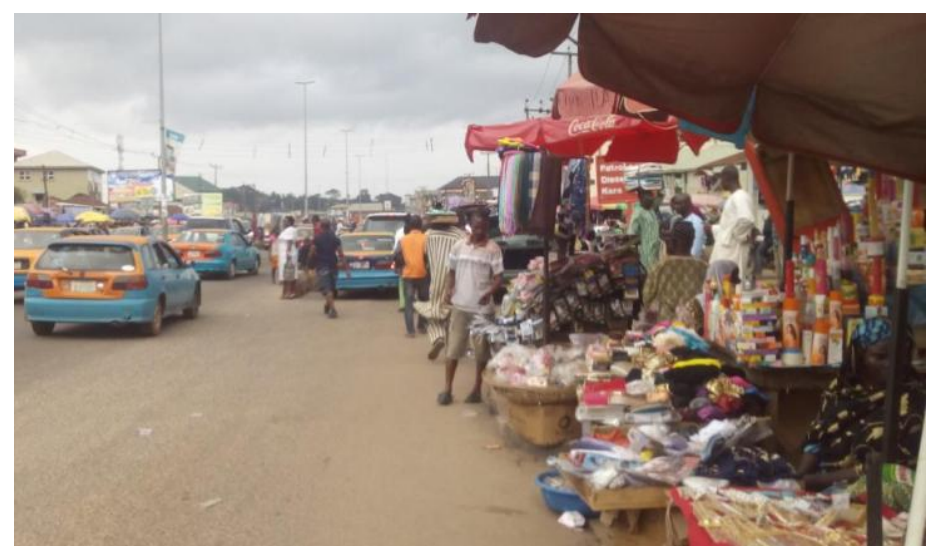

Plate6. Street trading at Oja Oba

Source: Author's Field Survey, 2016

\subsubsection{Level of On-Street Parking}

From the analysis of data collected in table 4.9. It was observed that the level of on-street parking at Oja Oba market was "not strong" as suggested by $8 \%$ of the respondents, another $8 \%$ of the respondents revealed that the level was "fairly strong", about $4 \%$ believed it was an "average" occurrence, and $60 \%$ of the respondents revealed it was "strong" while $20 \%$ reported it to be "very strong". From the responses of the respondents, it implies that the level of on-street parking is strong along the road in the market and calls for immediate attention. 
Table4.9. Level of On-Street Parking

\begin{tabular}{|l|l|l|}
\hline Level of On-Street Parking & Frequency & Percent \\
\hline Not strong & 4 & 8.0 \\
\hline Fairly strong & 4 & 8.0 \\
\hline Average & 2 & 4.0 \\
\hline Strong & 30 & 60.0 \\
\hline Very Strong & 10 & 20.0 \\
\hline Total & $\mathbf{5 0}$ & $\mathbf{1 0 0 . 0}$ \\
\hline
\end{tabular}

Source: Author's Field Survey, 2016

\section{SumMary OF Findings, RECOMMENDATION AND CONCLUSION}

\subsection{Summary of Findings}

This study showed that there was a relationship between commercial activities and transportation problems in Akure,South Local government. From the analysis, the significant of urban transportation system was not just a factor affected by commercial activities but as a factor that links and relates to other factors such as urban growth, value of land, and demand for commercial and economic attributes together. As rightly put by Okoko (2006), that land use pattern of a town is interrelated with the physical characteristics of its transportation network. Therefore, this research justifies the effects of commercial activities on transportation route in urban centres in Nigeria, a case of Oja Oba, Akure, Ondo State. The analysis showed that most Akure dwellers make used of private cars, taxi and Motorcycle as means of transportation from origin usually homes to their destination either work place or market. These research findings showed that transportation plays a significant role in the commercial society as it serves as a major source of income for some; for example, taxi drivers and motorcyclists, as shown from the research that the buyers convey their goods through taxis. In addition, the research showed that almost all visitors in the market area were Akure residents; this implies that the market was patronized by every dweller of Akure in total, which on the other hand produce a high flow of patronage and cause traffic congestion in the market area.

Furthermore, the rate of queuing caused by vehicles parked on the roadside and traders selling on the road depict poor state of the market area, because of lack of management; that is, making stalls available to traders and prohibiting the use of roadside for trading. The respondents expressed their displeasure on the side effect of the situation at Oja Oba. The research showed that despite the laudable merits of transportation, it exacts some negative externalities on the environment like; noise pollution from car horn and "hawkers' cry", air pollution from car exhaust s and odour that are generated from the environment. In conclusion, the level of traffic congestion was tied to two factors, on street parking and street trading which was interpreted to be strong and rampant in the market. It showed that the commercial activity within the area has a direct impact on the transportation route, in the sense that the flow of traffic is high and slow. From observations gotten on the field, some drivers or people in the car patronized hawkers and street traders.

\subsection{Recommendations}

With the alarming increase of commercial and urban transportation problems in Akure, it is only logical to make some suggestions that would assist to alleviate some of the problems. Based on the suggestion provided by the respondents and deductions from the research findings, the following recommendations are made in order to guide government, policy makers and relevant bodies on the need for effective use of transport systems and strategies to aid urban growth. The problem of traffic and environmental issues can be checked through the eradication of on street trading, fining the drivers that involve in on-street parking, they should be mandated to use the parking lot around the area. The adoption of traffic management technique such as road enhancement scheme, traffic signs, traffic warden, vehicles parking regulations and controls, modernization of junction control will help in reducing traffic congestion in the area and these strategies will provide orderliness on the road. In general, roads condition and transportation infrastructure in the study area should be given a face lift so as to attain a better road infrastructure and enhance transportation of goods and service to promote the economy attributes which in turn influence the growth of Akure.

With the advent implementation of the above recommendations, Akure as a whole will look more aesthetic and functional pleasing environment for establishment of industries both local and international which will aid the growth of Akure metropolis. 


\subsection{Conclusion}

The attempt of the professional scholars, internationally and locally have pinned point the contribution of extensive flows of commercial and transportation transactions that characterize the contemporary global economy system such as mobility, accessibility, increase land value and income level. It is evident in the study of transportation has influenced the growth of Akure South Local Government. Despite its laudable merit that transportation has on commercial areas, finding also believed that commercial activities influence the transportation system and invariably has environmental side effects such as noise pollution, air pollution that emerged because of car usage. It was noted in the research that street trading and on street parking should be banned and eradicated.

\section{REFERENCES}

Aderamo, A.J. (1990). Road Development and Urban Expansion: The Case of Ilorin, Nigeria.

Ph.D. Thesis submitted to the Department of Geography, Ilorin: University of Ilorin,

Aderamo, A. J. (2012). A Graph Theoretic Analysis of Intra-Urban Road Network in Ilorin, Nigeria. Research for Development. 17, 1 \& 2; 18, 1 \& 2 (December 2003), 221 - 240.

Churchill Anthony and Bier, G., (1976). "The Task ahead of the Cities in the Developing Countries," World Development. 4.363-409.

Kothari C.R (2004). Research methodology and techniques second revised edition. New age international publishers

Okoko E. (2006). Transportation Planning and Modelling, Millennium Publishers.

Ogunbodede, E. F and Aribigbola, Afolabi (2003). Traffic Management Practices and Problems in Akure, Nigeria, Indian Journal of Transport Management. Vol.27 No 3 July-September 2003 pp305-322.

Ogunbodede, E. F. (2009). Assessment of Traffic Congestion in Akure, Nigeria using GIS Approach: Lesson and Challenges for Urban Sustenance. Retrieved 20/12/2011,from: http//download.suemot.org/Conference-2007/Papers/O gunbodede.pdf

Oyinloye M, Omole F, Basorun J (2012). Elements of Basic Geography, published by Federal University of Technology Akure, ISBN 978-38403-5-5, page 94-98.

Litman, T.,(2015). Land Use Impacts on Transportation, Victoria Transport Policy Institute. (www. vtpi.org); at www.vtpi.org/landtravel.pdf

Wikipedia. (2015, October 30). commercial area. Retrieved from Wikipedia: https://en.Wikipedi a.org/wiki/Commercial_area

Yago, G. (1983). The Sociology of Transportation. Annual Review of Sociology, 9, 171-190. 